\title{
The impact of lateral localization of the procedure on the effectiveness of transplations of pre-implantation embryos in heifers-recipient
}

\author{
L. Roman ${ }^{1}$, S. Sidashova ${ }^{2}$, I. Popova ${ }^{1}$, N. Stepanova ${ }^{1}$, V. Chornyi ${ }^{1}$, P. Sklyarov³, \\ L. Koreyba ${ }^{3}$, B. Gutyj ${ }^{4 *}$ \\ ${ }^{1}$ Odessa State Agrarian University, 13 Panteleymonyvska St, Odessa, 65012, Ukraine \\ ${ }^{2}$ Agrarian doradcha (advisory) service of Odessa region, \\ 13 Panteleymonyvska St, Odessa, 65012, Ukraine \\ ${ }^{3}$ Dnipro State Agrarian and Economic University, st. S. Efremova, 25, Dnipro, 49600, Ukraine \\ ${ }^{4}$ Stepan Gzhytskyi National University of Veterinary Medicine and Biotechnologies, \\ 50 Pekarskaya St, Lviv, 79010, Ukraine \\ *Corresponding author E-mail: bvh@ukr.net \\ Received: 19.10.2020. Accepted 28.11.2020
}

\begin{abstract}
The article presents the results of a study of the efficiency of transcervical embryo transplantation obtained from donor-cows in vivo. The aim of the experiment was to compare the effectiveness of ipsilateral transfers randomized laterally from the uterine horn of embryos of different stages of development (blastocysts and morulas). The embryos were located in the left or right horn of the uterus of recipient heifers ( $n=283$ cows). It was experimentally established that the functional asymmetry of the ovaries of the recipients affects the level of survival of preimplantation embryos. Thus, in case of transfer to the left horn of the uterus of the recipients blastocysts $60.91 \%$ of pregnant heifers were found; morulas - $45.45 \%$. In case of similar procedures in the right horn of the uterus - were found respectively $58.78 \%$ and $14.29 \%$ pregnant. The obtained results indicate the need for further scientific research to study the structural and physiological features that affect the survival rate of preimplantation embryos.
\end{abstract}

Key words: donor cows, recipient heifers, embryo transfer, blastocysts, morulas, transferable embryos, ipsilateral localization.

\section{Introduction}

Due to significant scientific and technological advances in reproductive biotechnology and the full provision of high-tech equipment to producers in recent years cattle embryo transplantation (TE) has become widespread in recent years in developed livestock countries. The use of transplant animals is increasingly important for intensive reproduction of highly productive animals, both for breeding progress and an increase of milk yield in industrial complexes (Anderson, 1983; Iablonskyi, 2011; Dovhopol et al., 2010; Podoba et al., 2013; Roman et al., 2020). The advantage of the method of embryo transplantation is the ability to obtain much more offspring from record-breaking cows than in physiological reproduction by replication of valuable female genotype with help of reproductive biotechnology. The potential of ovaries of cows is $300-400$ thousand embryonic cells capable of further development. However, only one, rarely two eggs ovulate during one sexual cycle, therefore, only one calf is born from the cow per year (Melnyk et al., 2012; Melnyk \& Sidashova, 2013; Buhrov \& Tkachova, 2013; Grymak et al., 2020). In the current economic challenges of dairy agribusiness, a fuller use of the biological potential for reproduction of highly productive herds is achieved with the help of embryo transplantation. According to world statistics (www.iets.org), in 2018 the United States, Canada, Brazil, Russia are the leaders among 22 European countries - members of the Association for the production of genetic resources - embryos of various breeds of cattle (Madison, 2019). In these countries, transcervical transplants were performed on recipient cows and heifers, respectively: 421, 852, 50, 930, 296, 077, 41, 670 of quality embryos from dairy and beef cows. According to statistics for the same period in a number of leading countries there were conducted 9.981 embryo transfers (Netherlands), 4.822 (USA), 4.115 (Canada), 3.857 (Finland), 1.447 ( RF) per 1.000 cow of livestock (Madison, 2019). The same sources, for comparison, provide data on countries-outsiders in the development of biotechnology TE today: 0.073 (Namibia), 0.069 (Estonia), 0.013 (Greece), 0.006 (Ukraine). In Ukraine Currently there are adverse conditions for the development of biotechnology TE in Ukraine. However, the positive experience of previous years and the prospects of 
this area in the nearest future shoud be taken into consideration (Madison \& Madison, 2008; Melnyk \& Sidashova, 2013; Sidashova, 2013; Sidashova et al., 2016).

The advantages of embryo transplantation are fully realized only under certain organizational and economic conditions: full feeding, comfortable maintenance of recipient donors, complete set of TE with quality drugs and equipment, the presence of highly qualified specialists - biotechnologists (Melnyk et al., 2012; Buhrov \& Tkachova, 2013).

The efficiency of embryo transfer and the level of pregnancy in the recipient animal limit the final effectiveness of all previous biotechnological procedures and significantly affect the profitability of reproduction of the herd. This indicates the high relevance of studying the factors influencing the results of transcervical transplantation of cattle embryos.

In the literary references factors influencing the level of pregnancy in recipient animals after transcervical embryo transplantation are poorely described. This can probably be explained by the significant and heterogeneous influence of paratypical factors associated with technological, organizational, climatic and economic characteristics of the conditions of the recipient herds, which are difficult to be analyzed. The data presented in numerous foreign and domestic studies on the impact on the effectiveness of viability of transplanted pre-implantation embryos of different phases of development during transfer reveal a number of differences (Anderson, 1983; Melnyk et al., 2012; Danchuk et al., 2020; Bollman et al., 2020; Roman et al., 2020). There are well-known recommendations regarding more effective ipsilateral (from the ovary with corpus luteum) embryo transfers compared to contralateral (in the opposite horn of the uterus from the ovary with corpus luteum). Nevertheless, the effectiveness of ipsilateral transplants in the left or right horn of the recipient is still being discussed, which attests to the insufficient research of this issue.

The aim and task of our study was to determine the effect of lateral localization of ipsilateral transplantation of embryos of different age on the effectiveness of embryo survival in the left or right horn of the uterus of recipient heifers.

\section{Materials and Methods}

The experiments were conducted during 2010-2012 on the basis of the Embryo Transplant Laboratory "Poltavaplemservice" (state certificate № 8054 (Sidashova, 2013)). Embryos were obtained in vivo from regular donors ( $\mathrm{n}=28 \mathrm{heads}$, from highly productive cows bred from the main dairy herd due to the end of lactation) of Ukrainian red-spotted and Holstein breeds with a productivity of $9.000-14.000 \mathrm{~kg}$ of milk for better lactation. To stimulate multiple folliculogenesis, conventional protocols of induction of poliovulation (FSH 50 mg; PG F2a 500 mg) were used (Madison \& Madison, 2008; Dovhopol et al., 2010; Melnyk et al., 2012), detailed schemes of which are described in our previous publications. Artificial insemination was performed with deconserved sperm received from outstanding Holstein breeders of foreign selection, twice during the period of induced sexual arousal of the donor cow under manual control of the onset of complete ovulation of all mature follicles. Washing of the uterine cavity was performed on 7-th day after artificial insemination with the rectal control of the number of ovarian corpora lutea (Duvanov, 2011; Sidashova, 2013; Sidashova et al., 2019). A removal of preimplantation embryos from the donor uterine cavity was performed transcervically by self-flowing method using phosphate-saline Dulbecco buffer with the addition of $20 \%$ fetal calf serum and $0.075 \mathrm{mg} / \mathrm{ml}$ kanamycin sulfate (350-500 $\mathrm{ml}$ of warm medium for each horn of the uterus).

After the removal of the entire wash medium from the donor uterine cavity, the embryo was subjected to a comprehensive visual assessment of morphological structure and stage of development considering the day of previous insemination of the cow (7 days after the first insemination). The evaluation was performed in a sterile box under a binocular microscope with 1428 times of magnification (MBS-9). Quality assessment was performed in accordance with the generally accepted requirements for embryo transplantation and guidelines of a number of authors (lablonskyi, 2011; Melnyk \& Sidashova, 2013; Roman et al., 2020). The complaince of the conformity of the morphological development of the embryo to the term after fertilization, the state of cell mass and membranes, the nature of the connection between blastomeres, the state of the cytoplasm, the transparency of the pereviteline space were considering during visual control in vitro. Biologically complete embryos must be a clear spherical shape, have a light homogeneous cytoplasm, an intact transparent membranes and blastomeres of the same size with a dense intercellular complex (polygonal ligaments). The embryos were considered defective in case they had blastomeres of different sizes (asynchrony of development) with faint cell membranes and other signs of degeneration (decay). In accordance with the task of the experiment from the general embryo collection (Fig. 1) only high-quality synchronous transferable embryos were selected for subsequent use in the transfer of recipients (Fig. 2). Their age was determined according to the working scale based on generally accepted requirements and modified according to process of TE Laboratory (Table 1) (Dovhopol et al., 2010; Sidashova, 2013). Embryos that did not meet these characteristics were considered nontransferable and excluded from further work. No embryos were used in the stage of expanded blastocysts, due to the lack of a protective transparent membranes.

Transferable embryos were prepared according to current requirements relevant to the task of the study( marking on the payettee). Those emdryos were used for transcervical transfer to recipient heifers for a period of two to 6 hours after removal (Melnyk et al., 2012).

Preparation of recipient heifers was performed according to the conventional method by synchronizing the sexual cycle with the donor cow for embryo transfer for 7-7.5 days after the first insemination of the donor (Melnyk et al., 2012; Melnyk \& Sidashova, 2013). Synthetic prostaglandin F2a preparations (Estrofan $2 \mathrm{ml} / c o w$, Enzaprost $5 \mathrm{ml} /$ cow, intramuscularly) were used to synchronize the sexual cycle of recipients. According to previously applied modifications, drugs for lysis of ovarian luteal cells were administered once only under the control of the presence of a typical functional corpus luteum on one of the ovaries (Duvanov, 2011; Sidashova, 2013; Pereira et al., 2016; Nowicki et al., 2017; Sidashova et al., 2019). According to the task of the experiment, the selection of embryos for transfer was performed randomly to the lateral localization in the horns of the donor 
uterus, but clearly ipsilateral to the location of the functional corpus luteum on the right or left ovary of the recipient. All transfers were performed with the same type of catheters, at the same depth of the uterine horn of the recipient (one embryo for each recipient).
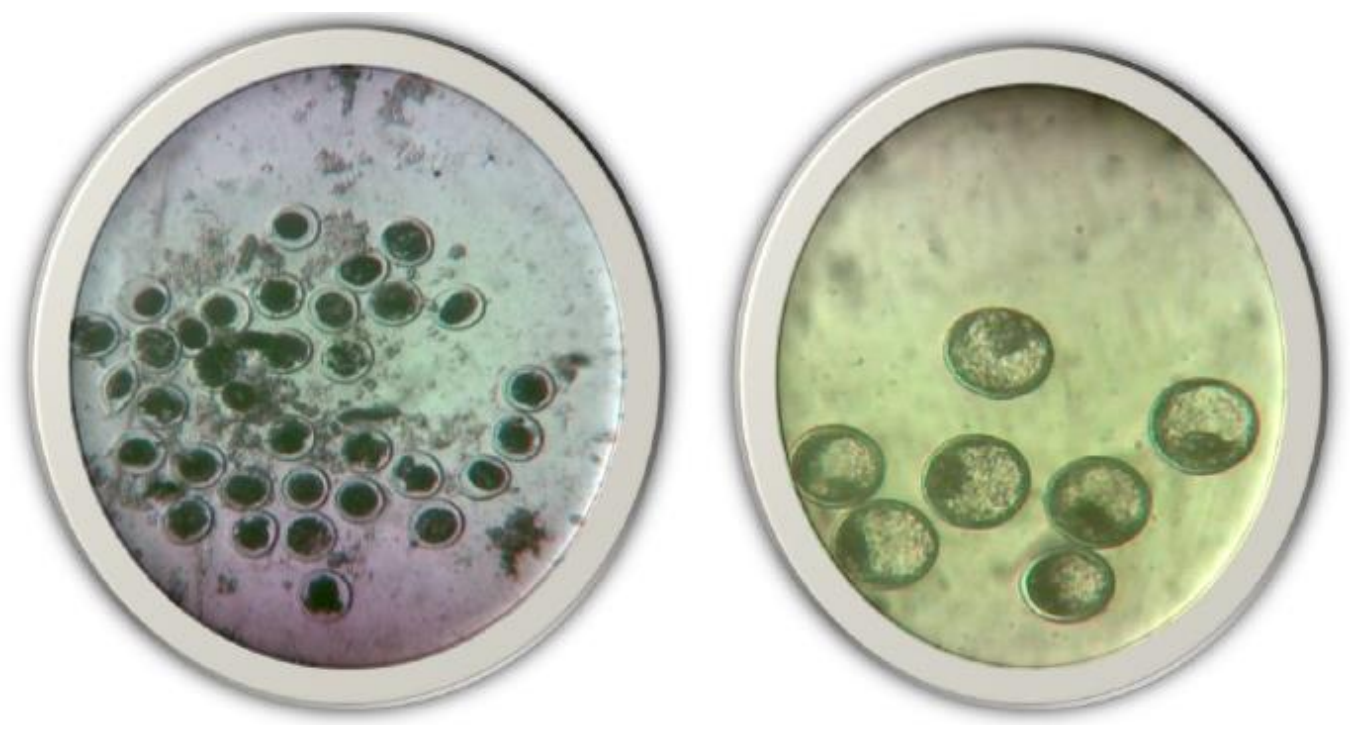

Fig. 1-2. On the left - a view of the general embryo collection in vivo, washed from the uterine cavity of the donor cow, under the microscope: the contents of the embryo include high-quality and degenerate embryos, unfertilized eggs, embryos that have stopped developing on the stage of two or four blastomeres (x28 in vitro); on the right - transferable early, middle and late blastocysts of excellent and good quality (5 and 4 points). Photo from the archive of the Embryo Transplant Laboratory "Poltavaplemservice", 2012) (Sidashova, 2013; Sidashova et al., 2016)

Table 1. Scale of visual evaluation in vitro of transferable bovine embryos obtained in vivo from donor cows, by stagemorphological features

\begin{tabular}{lc}
\hline $\begin{array}{c}\text { Abbreviated } \\
\text { name }\end{array}$ & Evaluation of the embryo by stage of development and morphological quality \\
\hline B P / S 5 & Blastocyst excellent 5 points (late or middle) \\
B P / S 4 & Blastocyst good 4 points (late or middle) \\
B P / S 3 & Blastocyst satisfactory 3 points (late or middle) \\
BE 5 & Blastocyst early excellent 5 points \\
BE 4 & Blastocyst early good 4 points \\
BE 3 & Blastocyst early satisfactory 3 points \\
M 5 & Morula excellent 5 points (late or early) \\
M 4 & Morula good 4 points (late or early) \\
M 3 & Satisfactory satisfactory 3 points (late or early). \\
\hline
\end{tabular}

All biotechnological procedures were performed by fixing animals in special machines, during the experiments no animal were harmed (Does et al., 1984).

In 35 days after the transfer, all recipients underwent ultrasound diagnosis to establish pregnancy, the data was entered in the acts of examination of heifers. The summarized data was presented in a table and subjected to biometric processing in accordance with generally accepted methods (Lakin, 1990).

\section{Results and Discussion}

The results of investigation showed that the average level of survival of preimplantation embryos in recipient heifers $(n=283$ cows) differs depending on the location of the transfer site in the right or left horn of the uterus, subjected to ipsilaterality during transfer (Table 2).

Transfer procedures were performed only in the recipient's uterine horn, ipsilaterally to location of the functional ovary with a developed corpus luteum, and used embryos were from a randomized sample of lateral origin from the left or right horn of the donor. Therefore, the level of pregnancy of recipient with left localization of transfer were $59.50 \pm 7.10 \%$, and with the right $54.94 \pm 7.04 \%$, which is $5.44 \%$ less. It should be noted that the correlation between the average survival rates of embryos had no probable connections $(P>0.05)$, but in consideration the individual stages of embryo development, in particular blastocysts $(n=258)$ the difference was highly probable, namely: the survival on the left was $60.91 \pm 2.66 \%$, and on the right $-58.78 \pm 2.99 \%$ $(C V=9.41 \%, t d=2.133, P<0.01)$. 
Table 2. The effectiveness of transcervical transplants of fresh preimplantation embryos of cows obtained by the in vivo method to recipient heifers $(n=283)$

\begin{tabular}{lccccc}
\hline \multirow{2}{*}{$\begin{array}{c}\text { Assessment of the } \begin{array}{c}\text { Transfers } \\
\text { embryo }\end{array} \\
\text { made, cows }\end{array}$} & $\begin{array}{c}\text { Embryo transplants in the recipient's } \\
\text { horn * }\end{array}$ & $\begin{array}{c}\text { Embryo transplants in the recipient's } \\
\text { right horn * }\end{array}$ \\
\cline { 3 - 6 } & & All transfers, cows & $\begin{array}{c}\text { Become } \\
\text { pregnant, }\end{array}$ & All transfers, cows & $\begin{array}{c}\text { Become } \\
\text { pregnant,\% }\end{array}$ \\
\hline B P / S 5 & 125 & 44 & 56,82 & 81 & 31,73 \\
B P / S & 32 & 18 & 72,22 & 14 & 50,00 \\
B P / S & 5 & 2 & 50,00 & 3 & 33,33 \\
BE 5 & 58 & 28 & 60,71 & 30 & 56,67 \\
BE 4 & 34 & 17 & 50,82 & 17 & 58,82 \\
BE 3 & 4 & 1 & 100,00 & 3 & 66,67 \\
M 5 & 16 & 7 & 54,17 & 9 & 22,22 \\
M 4 & 4 & 1 & 100,00 & 3 & 0,00 \\
M 3 & 5 & 3 & 0,00 & 2 & 0,00 \\
At once M $\pm m$ & 283 & 121 & $59,50 \pm 7,103$ & & $54,94 \pm 7.038$ \\
$\sigma$ & & & 18,794 & & 18.621 \\
CV & & & 30,172 & & 38.169 \\
& & & $P>0.05$ & & P>0.05 \\
\hline
\end{tabular}

Notes: * - ipsilaterally to the localization of the functional ovarian corpus /uteum

Figure 3 shows the relationship between the effect of the embryonic stage on the effectiveness of embryo transfers and the localization of the ipsilateral transplant procedure in the uterine horn of the recipients. Our data confirms the conclusions of most authors on the higher efficiency of use of preimplantation embryos in the blastocyst stage for transcervical transfer compared with the earlier stage of morulas (Madison \& Madison, 2008; Melnyk et al., 2012; Roman et al., 2020).

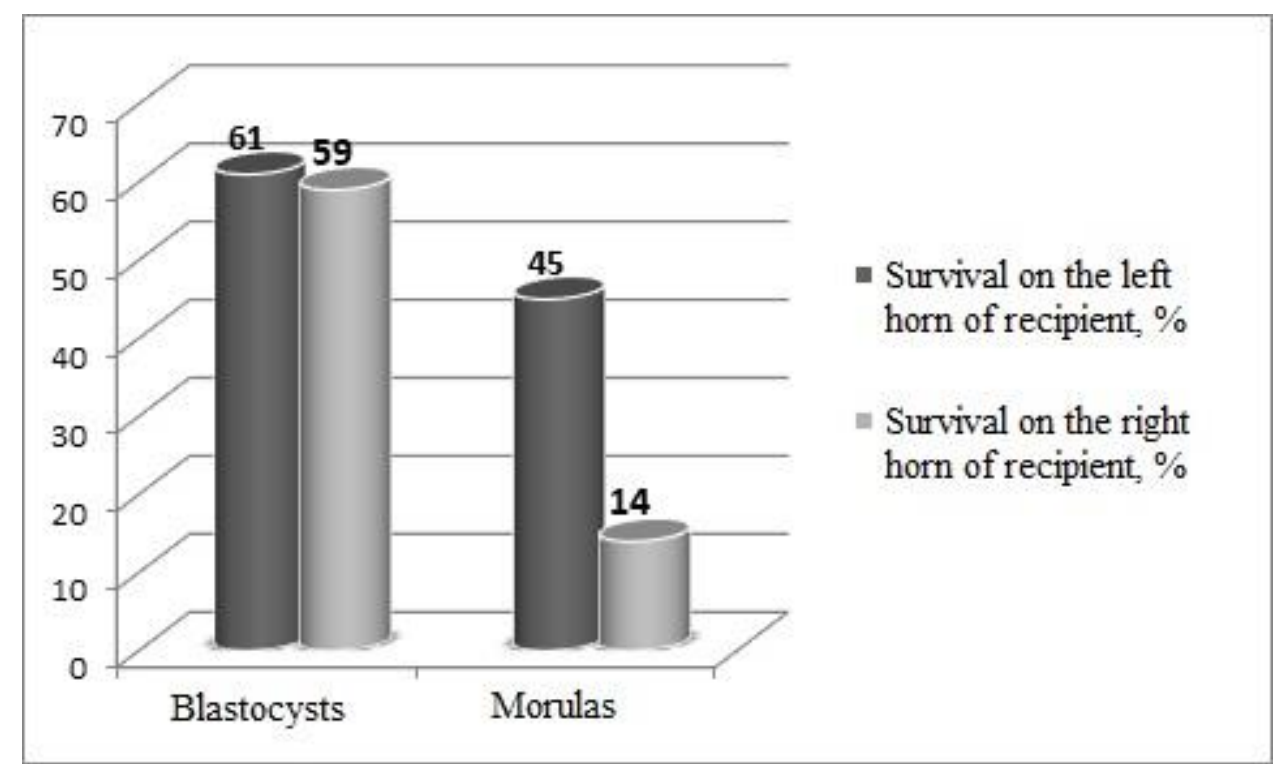

Fig. 3. The results of the lateral difference in the survival of pre-implantation embryos of different ages of development under the condition of ipsilateral transfers to recipient heifers $(n=283)$

The data shown in Figure 4 described that the high quality of preimplantation embryos was crucial for the efficiency of obtaining the recipient's pregnancy. In particular a high level of survival remained at the stage of blastocyst development regardless of the lateral location of the embryo transfer (from 57 to $63 \%$ of pregnant recipients). However, it had been established that functional asymmetry of the ovaries impact survival of embryos at the stage of morula: on the right there were $31.16 \%$ less of pregnant recipients with a corpus luteum than on the left. The data indicates the presence of complex, as of yet insufficiently studied, physiological relationships between preimplantation embryos and cows with bilateral body structure, which was shown in our previous publications (FAO, 2010; Sidashova \& Sahlo, 2014; Sidashova et al., 2016).

We summarized the results of comparing the survival rate of cow embryos after transcervical transplantation to recipient heifers (Fig. 5). Our results showed that the level of pregnancy was high (58.88 - 59.38\%) in case embryos were transplanted ipsilaterally on stage of blastocysts (early, middle, late) in the right or left horn of the uterus. Comparison of the effectiveness of the onset of recipients pregnancy $(n=283$ ) after ipsilateral embryo transfer of embryos of different ages (regardless of the lateral localization of the embryo in the horns of the uterus of the donor-recipient). Embryo survival by a similar method, but in the stage of development of early or late morula $(n=25)$ was at the level of $28.00 \%$, i.e. twice less than in blastocysts. 


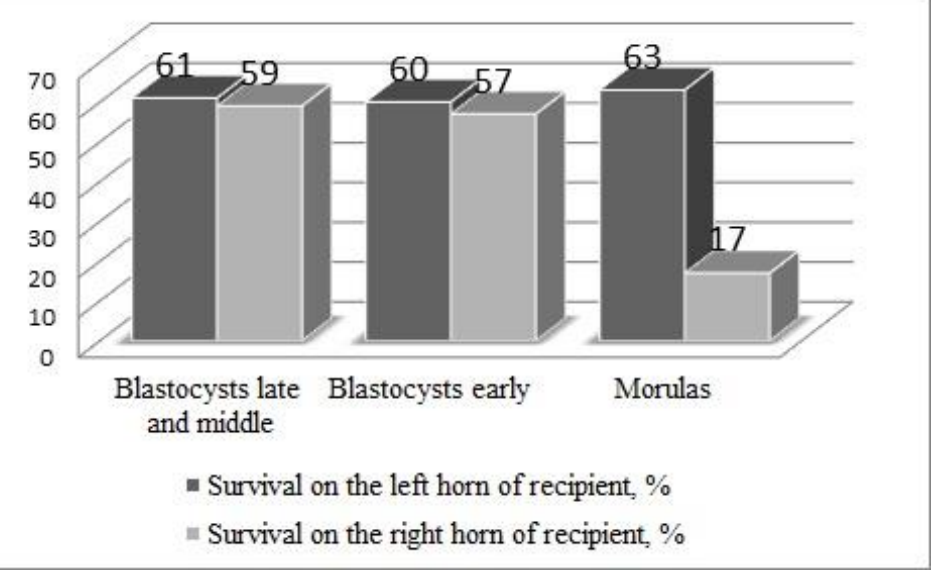

Fig. 4. The results of survival of embryos of high morphological quality under the condition ipsilateral transfers to recipient heifers $(n=269)$

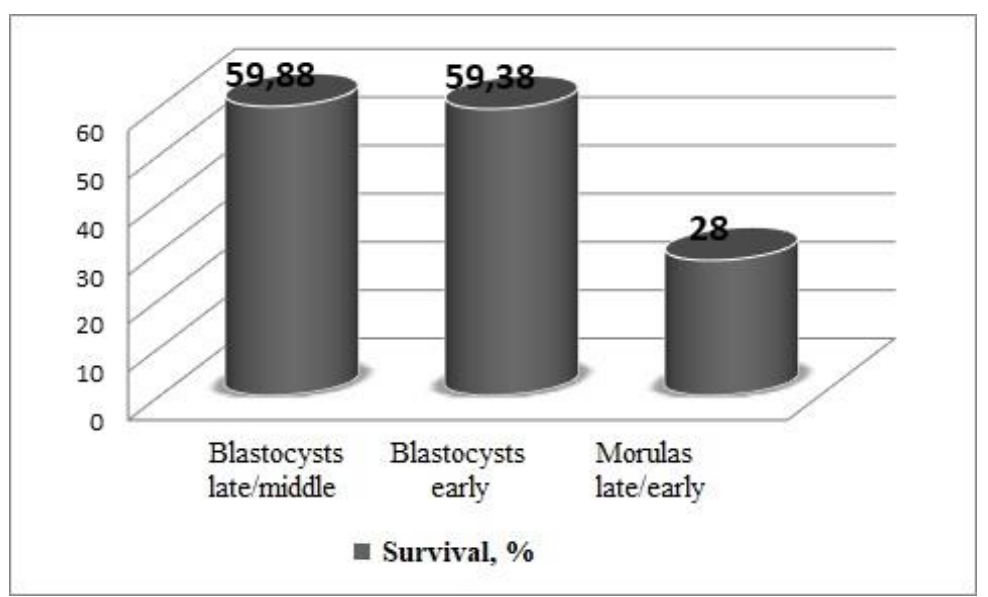

Fig. 5. Comparison of the effectiveness of the onset of pregnancy of recipients $(n=283)$ after ipsilateral embryo transfer of embryos of different ages (regardless of the lateral location of the embryo in the horns of the uterus of the donor-recipient)

The established difference was unreliable, which indicated a significant impact of heterogeneous paratypic factors on the effectiveness of embryo transfer procedures. Due to the heterochrony of maturation of follicles in the ovaries of cows under the influence of hormonal means of inducing poliovulation, embryos removed from the uterine cavity at different stages of development. Most authors agree with the conclusions on the better survival of blastocysts compared to morulas (except for the stage of expanded blastocysts) (Melnyk et al., 2012; Melnyk \& Sidashova, 2013). The considered data show the direction of scientific search of ways to increase the efficiency of embryo transplantation obtained in vivo, which may also apply to embryos obtained by in vitro methods.

\section{Conclusions}

It had been experimentally established that the lateral localization of ipsilateral embryo transfer procedures to recipient heifers affects the level of survival of preimplantation embryos obtained in vivo. In case of embryo transfer to the left horn of the recipient's uterus, the pregnancy rate was 59.50\%, in the right - 54.94\%.

The general level of embryo survival was significantly influenced by the stage of development of the preimplantation embryo: the onset of pregnancy was $60.91 \%$ of blastocysts (early, middle and late) after transfer to the left horn of the uterus in the right - 58.78\%, respectively. In case morulas (early and late) were transferred the level of the pregnancy was $45.45 \%$ on the left, $14.29 \%$ - on the right respectively.

\section{References}

Anderson, G. B. (1983). Embryo transfer in domestic animals. Adv.Vet. Sci, 27, 129-162.

Bollman, M., Greenhawk, A., Shipley, A., \& Gibbons, P. (2020). Ovarian profile and pregnancy rates following ovulation synchronization and timed-artificial insemination in dairy cows. College of Veterinary Medicine. Lincoln M.U., 1291-1300.

Buhrov, O. D., \& Tkachova, I. V. (2013). Znachennia metodu transplantatsii embrioniv u systemi selektsiinoi roboty z maloplodnymy vydamy tvaryn. Nauk.-tekhn. Biul, 113, 43-52 (in Ukrainian).

Danchuk, O. V., Karposvkii, V. I., Tomchuk, V. A. et al. (2020). Temperament in Cattle: A Method of Evaluation and Main Characteristics. Neurophysiology, 52, 73-79. https://doi.org/10.1007/s11062-020-09853-6 
Does, C., Stringfellow, D., \& Shultz, P. D (1984). Incorporation of follicle stimulating hormone used for embryotransfer in cattle into maltilamellar lyposomes. Theriogenology, 21(4), 661-675. https://doi.org/10.1016/0093-691X(84)90450-3

Dovhopol, V. F., Duvanov, O. V., \& Ivanchenko, M. I. (2010). Efektyvnist biotekhnolohii transplantatsii embrioniv velykoi rohatoi khudoby u Poltavskii oblasti. Veterynarna medytsyna, 13, 138-141 (in Ukrainian).

Duvanov, O. V. (2011). Morfolohichna kharakterystyka zhovtykh til yaiechnykiv i efektyvnist stymuliatsii poliovuliatsii koriv-donoriv. Rozvedennia i henetyka tvaryn: mizh vid. temat.nauk.zb. - K.: Ahrarna nauka, 45, 63-67 (in Ukrainian).

FAO. 2010a. № 3. Breeding strategies for sustainable management of animal genetic resources. FAO Animal Production and Health Guidelines. № 3. Rome. Italy: FAO of the UN, Commission on Genetic resources for Food and Agriculture, 2010.133 p.

Grymak, Y., Skoromna, O., Stadnytska, O., Sobolev, O., Gutyj, B., Shalovylo, S., Hachak, Y., Grabovska, O., Bushueva, I., Denys, G., Hudyma, V., Pakholkiv, N., Jarochovich, I., Nahirniak, T., Pavliv, O., Farionik, T., \& Bratyuk, V. (2020). Influence of "Thireomagnile" and "Thyrioton" preparations on the antioxidant status of pregnant cows. Ukrainian Journal of Ecology, 10(1), $122-126$. https://doi.org/10.15421/2020_19

lablonskyi, V. A. (2011). Veterynarne akusherstvo, hinekolohiia ta biotekhnolohiia vidtvorennia tvaryn z osnovamy androlohii; Pidruchnyk. Za redaktsiieiu Yablonskoho V.A. Vinnytsia: Nova knyha (in Ukrainian).

Lakin, N. F. (1990). Biometrija: uchebnoe posobie dlja biol. spec. vuzov. Moscow. Vysshaja shkola (in Russian).

Madison, V. V. (2019). Transplantacija jembrionov za 2019 god. [Elektronnij resurs]. Available from: https://www.dairynews.ru/newa/transplantasiya-embrionov-2019 (in Russian).

Madison, V. V., \& Madison, L. V. (2008). Poliovuljacija u korov-donorov - poisk prodolzhaetsja. NTB IT NAAN. Kharkiv, 96, $242-261$ (in Russian).

Melnyk, V. O., \& Sidashova, S. O. (2013). Akusherstvo, hinekolohiia i biotekhnolohiia vidtvorennia tvaryn. Konspekt lektsii. Mykolaiv (in Ukrainian).

Melnyk, V. O., Kot, S. P., \& Kravchenko, O. O. (2012). Akusherstvo, hinekolohiia i biotekhnolohiia vidtvorennia tvaryn: metodychni rekomendatsii. Ukladachi: Mykolaiv (in Ukrainian).

Nowicki, A., Baranicki, W., Baryczka, A., \& Janowski, T. (2017). Ovsyng protocol and modifications in the reproduction management of dairy cattle herds-an update. Jornal of Veterinary Research, 6(30), 329-336. https://dx.doi.org/10.1515\%2Fjvetres-2017-0043

Pereira, R. V., Caixeta, L. S., Giordano, J. O., Guard, C. L., \& Bicalho, R. C. (2016). Reproductive performance of dairy cows resynchronized after pregnancy diagnosis at 31 ( \pm 3 days) after artificial insemination (Al) compared with resynchronization at 31 ( \pm 3 days) after Al with pregnancy diagnosis at 38 ( \pm 3 days) after Al. Journal of Dairy Science, 96(12), 7630-7639. https://doi.org/10.3168/jds.2013-6723

Podoba, B. le., Kopylov, K. V., Kovtun, S. I., Kopylova, K. V., Podoba, Yu. V., \& Dobrianska, M. L. (2013). Molekuliarno-henetychni ta biotekhnolohichni doslidzhennia $v$ haluzi tvarynnytstva. K.: Ahrarna nauka (in Ukrainian).

Roman, L., Broshkov, M., Popova, I. Hierdieva, A., Sidashova, S., Bogach, N., Ulizko, S., \& Gutyj, B. (2020). Influence of ovarian follicular cysts on reproductive performance in the cattle of new Ukrainian red dairy breed. Ukrainian Journal of Ecology, 10(2), $426-434$. https://dx.doi.org/10.15421/2020_119

Roman, L., Sidashova, S., Danchuk, O., Popova, I., Levchenko, A., Chornyi, V., Bobritska, O., \& Gutyj, B. (2020). Functional asymmetry in cattle ovaries and donor-recipients embryo. Ukrainian journal of Ecology, 10(3), 139-146. https://dx.doi.org/10.15421/2020_147

Selk, G. (2014). Embryo transfer in cattle. Division of Agricultural Sciences and Natural Resources. Oklahoma Cooperation Service, 3158, 4-6.

Sidashova, S. O. (2013). Laboratoriia transplantatsii embrioniv "Poltavaplemservis". Svynarstvo, 62, $202-203$ (in Ukrainian).

Sidashova, S. O. (2013). Otsinka laktuiuchykh koriv buty prydatnymy donoramy - retsypiientamy doimplantatsiinykh embrioniv. Visnyk PDAA, 2, 61-63 (in Ukrainian).

Sidashova, S. O., \& Sahlo, O. F. (2014). Funktsionalna asymetriia honad samyts svynei i VRKh: metodolohiia vyvchennia, fundamentalni i prykladni aspekty. Svynarstvo, 64, 91-105 (in Ukrainian).

Sidashova, S. O., Gutyj, B. V., Khalak, V. I., \& Humeny, O. G. (2020). Influence of complex action of probiotic and specific prophylaxis of associated mucosal diseases on some quantitative traits of dairy cattle performance. Scientific Messenger of Lviv National University of Veterinary Medicine and Biotechnologies. Series: Veterinary sciences, 22(97), 79-87. https://doi.org/10.32718/nvlvet9714

Sidashova, S. O., Shcherbak, O. V., Kovtun, S. I., \& Trotskyi, P. A. (2019). Orhanizatsiia treninhu z diahnostyky stanu yaiechnykiv koriv i telyts za transplantatsii embrioniv. Chubynske (in Ukrainian).

Sidashova, S. O., Stakhovskyi, V. F., \& Kovtun, S. I. (2016). Embrioproduktyvnist koriv-donoriv i funktsionalna asymetriia yaiechnykiv. Rozvedennia i henetyka tvaryn: mizh vid. temat. nauk.zb. NAAN IRHT, 51, 247-255 (in Ukrainian).

Voitsitskiy, V. M., Danchuk, V. V., Ushkalov, V. Z., Midyk, S. V., Kepple, O. Yu., Danchuk, Z. V., \& Shevchenko, L. V. (2019). Migration of antibiotics residual quantities in aquatic ecosystems. Ukrainian Journal of Ecology, 9(3), 280-286. https://doi.org/10.15421/2019_742

Wiltbank, M., \& Purley, P. J. (2014). The cow as an induced ovulatory: Timed Al after synchronization of ovulation. Theriogenology, 81(1), 170-185. https://doi.org/10.1016/j.theriogenology.2013.09.017

\section{Citation:}

Roman, L., Sidashova, S., Popova, I., Stepanova, N., Chornyi, V., Sklyarov, P., Koreyba, L., Gutyj, B. (2020). The impact of lateral localization of the procedure on the effectiveness of transplations of pre-implantation embryos in heifers-recipient. Ukrainian Journal of Ecology, 106), $121-126$.

(cc) Br This work is licensed under a Creative Commons Attribution 4.0. License 